\title{
Synovial fluid concentration of five different cytokines in rheumatic diseases
}

Carole I Westacott, John T Whicher, Ian C Barnes, Douglas Thompson, Angela J Swan, Paul A Dieppe

\begin{abstract}
Interleukin-1 $\beta$, interleukin-2, tumour necrosis factor $\alpha$, and the interferons, alfa and gamma, were measured concurrently in synovial fluid samples from 68 patients with rheumatic diseases. Mean interleukin-1 $\beta$ concentrations $(130.3(\mathrm{SD} 22) \mathrm{pg} / \mathrm{ml})$ were higher in synovial fluids from patients with rheumatoid arthritis (RA) than in those from patients with osteoarthritis $(27.8(4.5) \mathrm{pg} / \mathrm{ml})$, while measurements in synovial fluids from patients with seronegative spondarthritis were intermediate (72.7 (32) $\mathrm{pg} / \mathrm{ml})$. Interleukin-2 and tumour necrosis factor $\alpha$ concentrations were lower in the inflammatory arthropathies (RA: 4.5 (0.6) $\mathrm{U} / \mathrm{ml}, 0.39(0.04) \mathrm{ng} / \mathrm{ml}$; seronegative spondarthritis: $3.1(0.3) \mathrm{U} / \mathrm{ml}, 0.33(0.03) \mathrm{ng} / \mathrm{ml}$ respectively) than those in patients with osteoarthritis $(5.2(0.6) \mathrm{U} / \mathrm{ml} ; 0.05(0.04) \mathrm{ng} / \mathrm{ml})$. Interleukin-2 and tumour necrosis factor $\alpha$ concentrations correlated in all groups $(r=0.7)$, as did the interferons alfa and gamma $(r=0 \cdot 7)$. There was no relation between interleukin-1 $\beta$ and either interleukin- 2 or tumour necrosis factor $\alpha$, or between the interferons and any other cytokine. Several distinct cytokine patterns were noted. Synovial fluids from two non-arthritic subjects were also examined: interleukin-1 $\beta$ concentrations were low, but concentrations of the other cytokines were higher than those seen in most arthritic fluids.
\end{abstract}

Inducible peptide cytokines associated with host defence, inflammation, and tissue repair have potential pathogenic activities which are particularly relevant to the rheumatic diseases. Interleukin-1 $\beta$ (IL-1 $\beta$ ), interleukin-2 (IL-2), tumour necrosis factor $\alpha$ (TNF $\alpha)$, interferon alfa, and interferon gamma are among the many cytokines that can act alone or in synergy as mediators of tissue damage or chronic inflammation and which have been implicated in the pathogenesis of arthritis. ${ }^{1}$

Interleukin-1 $\beta$ and $T N F \alpha$ are able to act locally to induce bone and cartilage resorption ${ }^{2-6}$ -a central feature of joint disease, and TNF $\alpha$ is also able to accelerate proteoglycan degradation. ${ }^{5}$ IL-1 $\beta$ and TNF $\alpha$ have many in vitro activities in common $^{7-9}$ - each can induce the production of the other as well as that of other cytokines, ${ }^{10}{ }^{11}$ and IL-1 $\beta$ can also induce IL-1 $\beta$ gene expression. ${ }^{12}$ Both cytokines, independently or together with interferon gamma can induce the proliferation of synoviocytes. ${ }^{1}$ 13-15 Interleukin-1 $\beta$ and TNF $\alpha$ may stimulate these cells to produce prostaglandins and proteases, ${ }^{16} 17$ and both TNF $\alpha$ and interferon gamma can induce chondrocyte production of reactive oxygen species, ${ }^{18}$ thereby potentially amplifying the destructive process. Interferons alfa and gamma can act together or alone to stimulate class II major histocompatibility complex antigen expression, ${ }^{19}$ resulting in potentiation of the inflammatory process through IL-2 induced mitogenesis of activated $\mathrm{T}$ cells, ${ }^{20}$ and further production of interferon gamma, ${ }^{1} \mathrm{IL}-1$, and TNF $\alpha .{ }^{15}$ Much of the evidence comes from in vitro studies and it is therefore difficult to draw conclusions about in vivo effects. Probably, however, the balance between cytokines is more important than the concentrations of individual cytokines.

Examination of joint fluid exudate for evidence of cytokine production by surrounding cells and tissues may provide some insight into disease activity, and several research groups have measured concentrations of cytokines in synovial fluids. Bioassay methods provide valuable information about the many receptor mediated activities of cytokines, though they do not necessarily reflect cytokine production due to interference by non-specific binding to other proteins. They are impractical for use with large numbers of samples.

With the recent introduction of cytokine immunoassays concentrations of many cytokines in biological fluids may be measured. We have studied the concentrations of five cytokines in synovial fluids from patients with both inflammatory and non-inflammatory arthritides in an attempt to determine whether different patterns of cytokine activity can be related to either diagnosis or disease pattern. This paper reports our initial cross-sectional data on the relative concentration of cytokines in synovial fluid.

\section{Patients and methods}

PATIENTS

Synovial fluid was aspirated from the knee joints of 68 patients with a variety of rheumatic diseases when indicated for diagnostic or therapeutic reasons. Thirty seven patients presented with classic rheumatoid arthritis (RA); 19 with clinical and radiological features of osteoarthritis-three with associated deposition of calcium pyrophosphate; 12 with various seronegative spondyloarthropathies (one juvenile chronic arthritis, one ankylosing spondylitis, four reactive arthritis, six psoriatic arthritis), who were combined to form a single group. Ten patients had fluid aspirated from both knees, two on more than one occasion, and 19 patients provided more than one sample from the same joint. 
Thirty nine patients ( 21 with RA, 10 with osteoarthritis, eight with seronegative arthropathies) were being treated with analgesics alone or in combination with non-steroidal antiinflammatory agents or steroid injection into the knee joint. Twenty nine patients (16 with RA, nine with osteoarthritis, four with seronegative arthropathies) were not receiving any drug treatment at the time samples were obtained.

\section{NON-ARTHRITIC SUBJECTS}

Fluid was aspirated from the knee joint of two subjects who tended to form 'fluid on the knee', but had no symptoms or evidence of arthritis: one healthy 54 year old man (subject 1), the other a healthy 47 year old woman, whose knee was aspirated after walking up stairs (subject 2).

\section{SYNOVIAL FLUID}

Synovial fluids were dispensed into sterile containers and estimation of cell numbers, viscosity, and turbidity made within two hours. Samples for assay were centrifuged $(1500 \mathrm{rpm}$, 15 minutes) to remove cellular debris before storage at $-70^{\circ} \mathrm{C}$. One hundred and eleven samples were collected over 18 months: 57 from patients with RA, 27 from patients with osteoarthritis, and 27 from patients with seronegative arthropathies. Fluids were assayed undiluted after further centrifugation $(18000 \mathrm{rpm}, 15$ minutes) to remove material precipitated by the freeze/thaw action.

\section{CYTOKINE MEASUREMENT}

All cytokine measurements were performed with duplicates of each sample.

Interleukin-1 $\beta$ was measured by amplified enzyme linked immunosorbent assay (ELISA; Cistron, New Jersey, USA). Plates precoated with monoclonal antibody to human IL-1 $\beta$ were incubated with $100 \mu$ synovial fluid (two hours, $37^{\circ} \mathrm{C}$ ), followed by further incubations with

Table 1 Clinical details of patients included in the study

\begin{tabular}{|c|c|c|c|}
\hline & $\begin{array}{l}\text { Rheumatoid } \\
\text { arthritis }(n=37)\end{array}$ & $\begin{array}{l}\text { Osteoarthritis } \\
(n=19)\end{array}$ & $\begin{array}{l}\text { Seronegative } \\
\text { spondarthritis } \\
(n=12)\end{array}$ \\
\hline $\begin{array}{l}\text { Sex } \\
\text { Age (years) }\end{array}$ & $28 \mathrm{~F}, 9 \mathrm{M}$ & $16 \mathrm{~F}, 3 \mathrm{M}$ & $4 \mathrm{~F}, 8 \mathrm{M}$ \\
\hline $\begin{array}{l}\text { Mean (SD) } \\
\text { Range }\end{array}$ & $\begin{array}{l}58 \cdot 9(12 \cdot 3) \\
19-75\end{array}$ & $\begin{array}{l}72 \cdot 9(12 \cdot 3) \\
52-91\end{array}$ & $\begin{array}{l}40(19 \cdot 6) \\
20-83\end{array}$ \\
\hline $\begin{array}{l}\text { Disease duration (years) } \\
\text { Mean (SD) } \\
\text { Range }\end{array}$ & $\begin{array}{l}12 \cdot 3(11 \cdot 2) \\
1-50\end{array}$ & $\begin{array}{l}12 \cdot 7(9 \cdot 4) \\
3-40\end{array}$ & $\begin{array}{l}10 \cdot 2(8 \cdot 4) \\
<1-27\end{array}$ \\
\hline $\begin{array}{l}\text { Effusion volume (ml) } \\
\text { Mean (SD) } \\
\text { Range }\end{array}$ & $\begin{array}{l}21 \cdot 4(23 \cdot 9) \\
1-147\end{array}$ & $\begin{array}{l}16 \cdot 6(14 \cdot 4) \\
2-72\end{array}$ & $\begin{array}{l}26 \cdot 7(22 \cdot 3) \\
1-70\end{array}$ \\
\hline
\end{tabular}

Table 2 Cytokine concentrations in synovial fluids. Results are given as mean (SD)

\begin{tabular}{|c|c|c|c|c|c|c|}
\hline \multirow[t]{3}{*}{ Cytokine* } & \multicolumn{2}{|c|}{ Rheumatoid arthritis } & \multicolumn{2}{|l|}{ Osteoarthritis } & \multicolumn{2}{|l|}{$\begin{array}{l}\text { Seronegative } \\
\text { spondarthritis }\end{array}$} \\
\hline & \multirow[t]{2}{*}{ Concentration } & \multirow[t]{2}{*}{$n$} & \multirow[t]{2}{*}{ Concentration } & \multirow[t]{2}{*}{$n$} & & \\
\hline & & & & & Concentration & $n$ \\
\hline 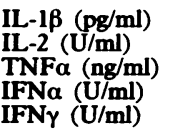 & $\begin{array}{c}130.3(22) \\
4.5(0.6) \\
0.39(0.04) \\
30.5(8.4) \\
4.4(0.9)\end{array}$ & $\begin{array}{l}57 \\
56 \\
54 \\
49 \\
43\end{array}$ & $\begin{array}{c}27 \cdot 8(4 \cdot 5) \\
5 \cdot 2(0 \cdot 6) \\
0 \cdot 5(0 \cdot 04) \\
41 \cdot 9(9 \cdot 9) \\
6 \cdot 7(1 \cdot 2)\end{array}$ & $\begin{array}{l}27 \\
27 \\
24 \\
18 \\
15\end{array}$ & $\begin{array}{c}72 \cdot 7(32 \cdot 0) \\
3 \cdot 1(0 \cdot 3) \\
0 \cdot 33(0 \cdot 03) \\
34 \cdot 3(8 \cdot 3) \\
4 \cdot 8(0.9)\end{array}$ & $\begin{array}{l}27 \\
26 \\
24 \\
23 \\
22\end{array}$ \\
\hline
\end{tabular}

*IL-1 $\beta=$ interleukin-1 $\beta$; IL-2=interleukin-2; TNF $\alpha=$ tumour necrosis factor $\alpha$; IFN $\alpha=$ interferon alfa; IFN $\gamma=$ interferon gamma. polyclonal rabbit anti-IL-1 $\beta$ (two hours, $37^{\circ} \mathrm{C}$ ) and goat antirabbit IgG conjugated to horseradish peroxidase (30 minutes, room temperature). Excess reactants were removed by washing three times between each step with phosphate buffer $(0.01 \mathrm{M}, \mathrm{pH} 7.4)$ containing $1 \%$ bovine serum albumin. Addition of enzyme substrate ( $o$-phenylenediamine; 30 minutes, room temperature) produced a chromogenic product, whose absorption was measured at 490 $\mathrm{nm}$. Assay sensitivity was $20 \mathrm{pg} / \mathrm{ml}$. Between and within batch variability (coefficient of variation), which was dependent on concentration, was not greater than $10 \%$ and $7 \%$ respectively (Cistron, New Jersey, USA).

Interleukin-2, $T N F \alpha$, interferons alfa and gamma were measured by radioimmunoassay (IRE-Medgenix, Fleurus, Belgium). Synovial fluid samples were preincubated with polyclonal rabbit antiserum to the relevant antigens ( 18 hours), followed by incubation with radiolabelled antigen (four hours) and antibodies to rabbit IgG suspended in a buffer containing polyethylene glycol, cellulose, and Tween 20 to aid precipitation ( 20 minutes). Incubations were performed at room temperature for IL-2, TNF $\alpha$, and interferon alfa and at $4^{\circ} \mathrm{C}$ for interferon gamma. Bound antigen was separated from free reactants by centrifugation ( 2400 $\mathrm{rpm}, 15$ minutes, $10^{\circ} \mathrm{C}$ ). Sensitivity for each assay was $1 \mathrm{U} / \mathrm{ml}$ for IL-2, $0 \cdot 1 \mathrm{ng} / \mathrm{ml} \mathrm{TNF} \alpha, 8 \cdot 2$ $\mathrm{U} / \mathrm{ml}$ interferon alfa, and $2 \mathrm{U} / \mathrm{ml}$ for interferon gamma. Between and within batch variability (coefficient of variation) for all four assays was dependent on concentration and not greater than $12 \%$ and $8 \%$ respectively (IRE-Medgenix, Fleurus, Belgium).

\section{REACTIVE PROTEIN MEASUREMENT}

Serum $C$ reactive protein was measured by immunoturbidometry using the COBAS Mira (Roche Products, Welwyn, Herts). Antiserum and calibrant were obtained from Atlantic Antibodies, Westbrook, Maine, USA. Between assay variability was $4 \cdot 2 \%$.

\section{STATISTICAL ANALYSIS}

Group differences were examined by MannWhitney U test and correlations by Spearman's rank correlation coefficient.

\section{Results}

Table 1 gives details of the patients studied. All had significant effusions in one or both knees requiring aspiration of fluid at the time of the study. Large variations were seen in the volume of fluid removed from the knees of different patients, in individual patients on different occasions, and in effusions from both knees of the same patients.

Synovial fluid $(10 \mathrm{ml})$ was aspirated from the knee joint of subject 1 and $3.5 \mathrm{ml}$ from the other control, subject 2 .

CYTOKINE CONCENTRATIONS IN SYNOVIAL FLUIDS FROM DIFFERENT DIAGNOSTIC GROUPS

Table 2 shows the mean and standard deviation of cytokine concentrations in patients classified 


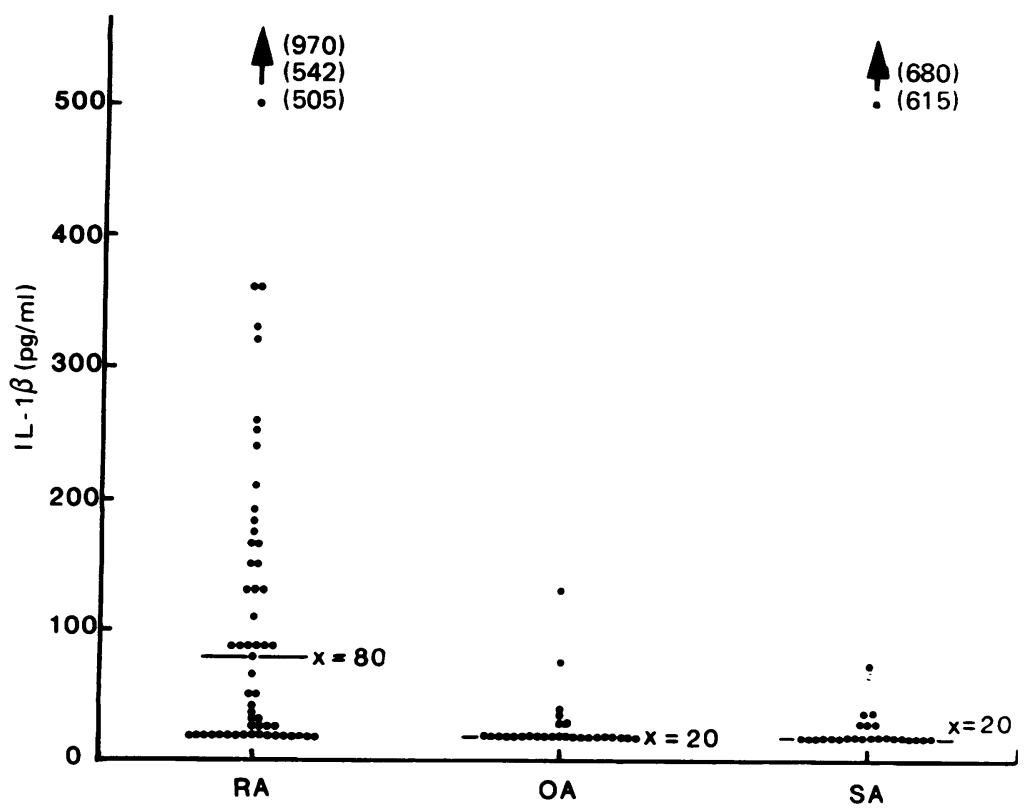

Figure 1 Interleukin-1 $\beta(I L-1 \beta)$ concentrations in synovial fluids from patients with rheumatoid arthritis $(R A)$, osteoarthritis $(O A)$, and seronegative spondarthritis $(S A)$ with median values indicated $(X)$. Mean values $(S D)$ were $130 \cdot 3(22), 27 \cdot 8(4 \cdot 5)$, and $72 \cdot 7(32)$ $\mathrm{pg} / \mathrm{ml}$ respectively. Measurements in the group with $R A$ were significantly higher than those in the other two groups $(p<0.001)$.

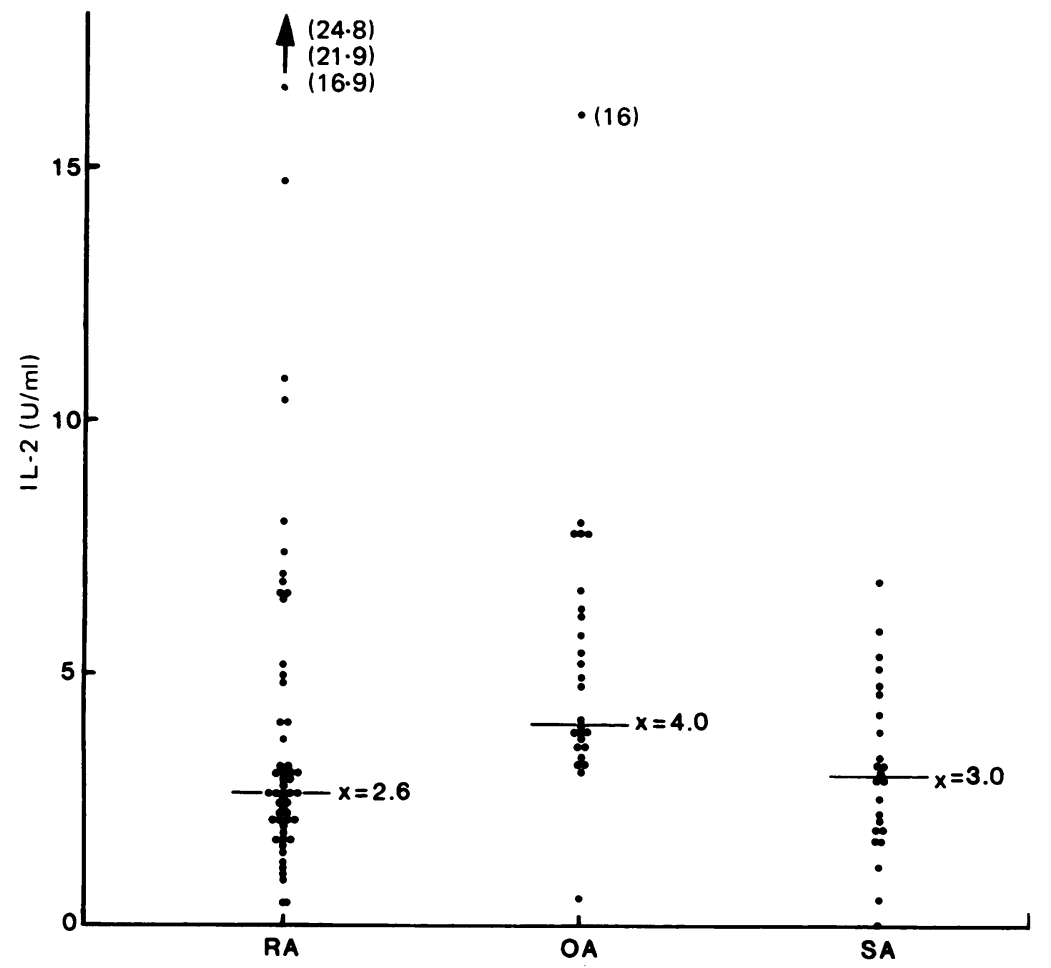

Figure 2 Interleukin-2 (IL-2) concentrations in synovial fluids from patients with rheumatoid arthritis $(R A)$, osteoarthritis $(O A)$, and seronegative spondarthritis $(S A)$ with median values indicated $(X)$. Mean values $(S D)$ were $4 \cdot 5(0 \cdot 6), 5 \cdot 2(0 \cdot 6)$, and $3 \cdot 1(0 \cdot 3)$ $U / m l$ respectively. Measurements in $O A$ were significantly higher than those in the inflammatory arthropathies $(p<0.01)$.

according to diagnosis. No significant difference in cytokine concentration was found between fluids from patients not receiving drug treatment $(n=39)$ and those receiving analgesics or anti-inflammatory agents $(n=29)$.

Mean IL-1 $\beta$ measurements were significantly higher in RA fluids than in those from patients with osteoarthritis or the seronegative arthritides $(p<0.001)$. Twenty one of 27 IL-1 $\beta$ measurements in the osteoarthritic group were at the
Table 3 Synovial fluid cytokine concentrations in patients with rheumatoid arthritis showing different patterns of interrelationship

\begin{tabular}{|c|c|c|c|c|c|}
\hline $\begin{array}{l}\text { Patient } \\
\text { No }\end{array}$ & $\underset{(p g / m l)}{I L-1 \beta^{*}}$ & $\begin{array}{l}I L-2 \\
(U / m l)\end{array}$ & $\begin{array}{l}T N F \alpha \\
(n g / m l)\end{array}$ & $\begin{array}{l}I F N \alpha \\
(U / m l)\end{array}$ & $\begin{array}{l}I F N \gamma \\
(U / m l)\end{array}$ \\
\hline $\begin{array}{l}1 \\
2 \\
3 \\
4 \\
5 \\
6\end{array}$ & $\begin{array}{r}20 \\
330 \\
177 \\
970 \\
20 \\
86\end{array}$ & $\begin{array}{r}14 \cdot 7 \\
2.4 \\
10.4 \\
6.6 \\
1.7 \\
6.9\end{array}$ & $\begin{array}{l}1.04 \\
0 \cdot 37 \\
0 \cdot 21 \\
0.74 \\
0 \cdot 1 \\
1.04\end{array}$ & $\begin{array}{r}150 \\
14.0 \\
45.0 \\
13.4 \\
5.0 \\
43.0\end{array}$ & $\begin{array}{r}29 \cdot 5 \\
1.4 \\
5.7 \\
1.0 \\
1.0 \\
12.2\end{array}$ \\
\hline
\end{tabular}

${ }^{*}$ For abbreviations see table 2 .

lowest detection limit of the assay $(20 \mathrm{pg} / \mathrm{ml})$ compared with 18 of 27 measurements in the seronegative group and 16 of 57 in the RA group.

Mean IL-2 and TNF $\alpha$ concentrations were significantly lower in fluids from those with the inflammatory arthropathies than in those from the group with osteoarthritis $(p<0.01)$, though the highest individual values were seen in RA. For all three cytokines greatest variance was seen within the group with RA (figs 1-3). Wide variation in interferon alfa and gamma measurement was seen in all three disease groups, and there was no significant difference between them.

VARIATION IN CYTOKINE PATTERNS IN DIFFERENT JOINTS

Large variations in the pattern of synovial fluid cytokine concentrations were seen between different patients and in bilateral effusions from the same patient. This was more apparent in fluids from patients with RA. In some patients with RA IL- $1 \beta$ concentration was high and all other measurements low, in some patients IL-1 $\beta$ was at the lowest detection limit of the assay and all other cytokine measurements high, and in others all cytokine concentrations were low (tables 3 and 4). No fluid showed all cytokine concentrations to be correspondingly high. Changes in sequential synovial fluid cytokine concentrations were also greater in patients with RA than in those with osteoarthris or seronegative arthritides (tables 5-7).

CYTOKINE CONCENTRATIONS IN SYNOVIAL FLUIDS FROM NON-ARTHRITIC SUBJECTS

Table 8 shows that cytokine concentrations were similar in both subjects. Interleukin-1 $\beta$ was at the lowest detection limit of the assay (20 $\mathrm{pg} / \mathrm{ml}$ ); concentrations of all other cytokines measured were higher than those seen in most samples from diseased joints.

\section{CORRELATIONS BETWEEN CYTOKINES}

A positive correlation was apparent in all groups between IL-2 and TNF $\alpha(r=0.7)$ and the interferons alfa and gamma ( $r=0.7)$ (figs 4 and 5). No correlation was found between IL-1 $\beta$ and either IL-2 or TNF $\alpha$ or between the interferons and any other cytokine.

\section{REACTIVE PROTEIN CONCENTRATION}

$C$ reactive protein concentrations in patient 11 (table 5) were significantly higher than normal $(<8 \mathrm{mg} / \mathrm{ml})$, indicating inflammation. 


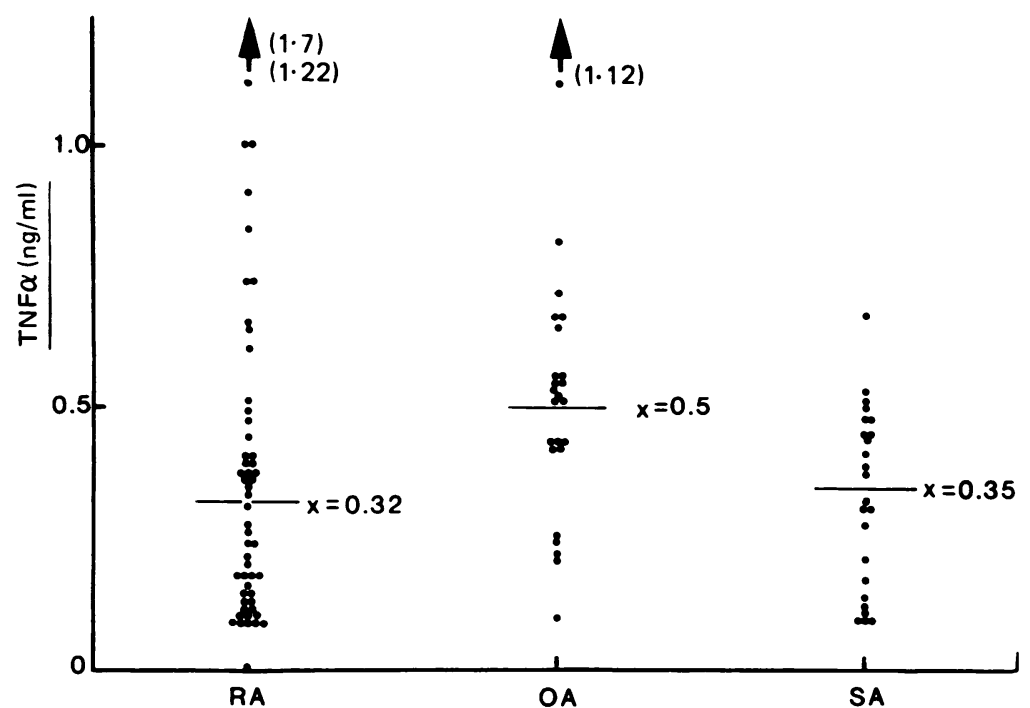

Figure 3 Tumour necrosis factor $\alpha(T N F \alpha)$ concentrations in synovial fluids from patients with rheumatoid arthritis $(R A)$, osteoarthritis $(O A)$, and seronegative spondarthritis $(S A)$ with median values indicated $(X)$. Mean values $(S D)$ were $0.39(0.04), 0.5(0.04)$, and 0.33 $(0.03) \mathrm{ng} / \mathrm{ml}$ respectively. Measurements in osteoarthritis were significantly higher than those in the inflammatory arthropathies $(p<0 \cdot 01)$.

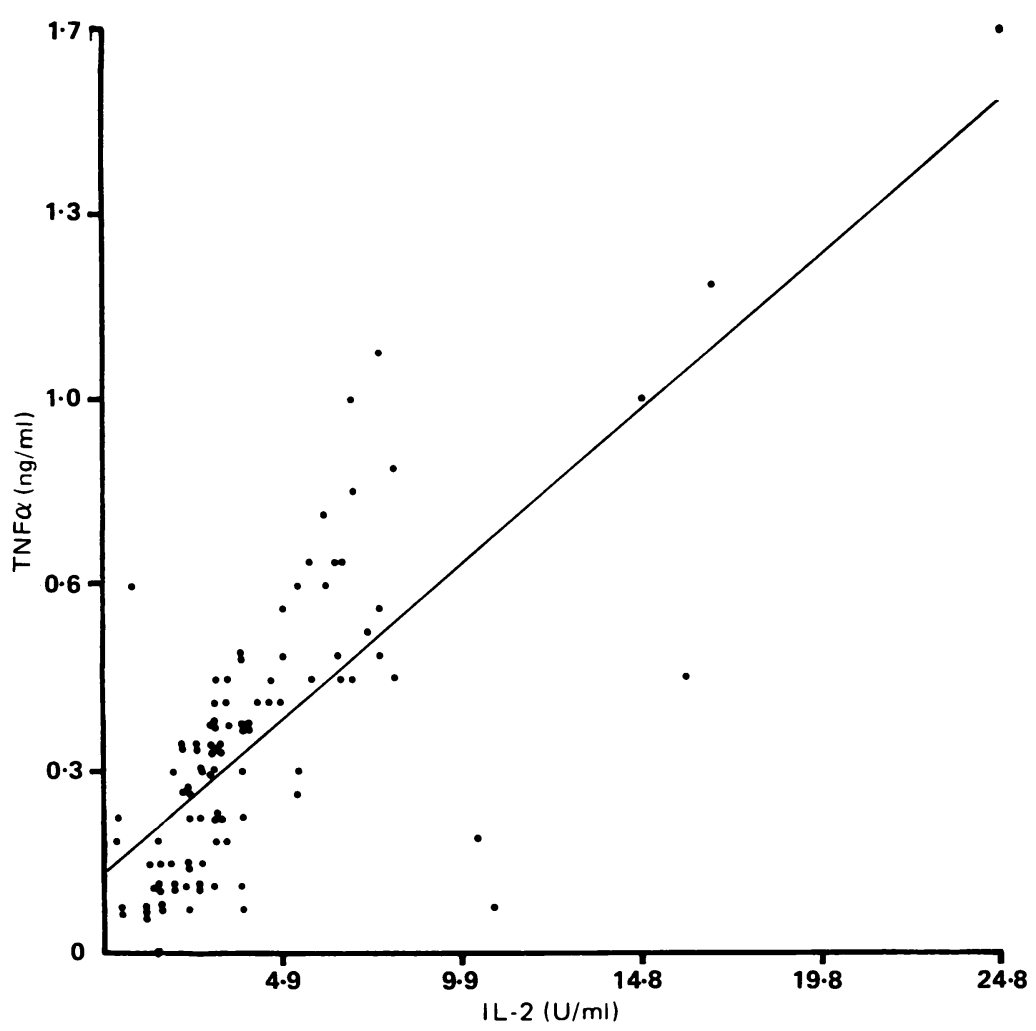

Figure 4 Correlation between interleukin-2 (IL-2) and tumour necrosis factor $\alpha(T N F \alpha)$ in synovial fluids from all three diagnostic groups $(n=102)$. Spearman's rank correlation coefficient $r=0 \cdot 7 ; p<0 \cdot 001$.

Table 4 Cytokines in synovial fluid from patients with rheumatoid arthritis with effusions from both knees

\begin{tabular}{|c|c|c|c|c|c|}
\hline $\begin{array}{l}\text { Patient } \\
\text { No:knee }\end{array}$ & $\begin{array}{l}I L-l \beta^{*} \\
(p g / m l)\end{array}$ & $\begin{array}{l}I L-2 \\
(U / m l)\end{array}$ & $\begin{array}{l}T N F \alpha \\
(\boldsymbol{n g} / \boldsymbol{m l})\end{array}$ & $\begin{array}{l}I F N \alpha \\
(U / m l)\end{array}$ & $\begin{array}{l}I F N \gamma \\
(U / m l)\end{array}$ \\
\hline 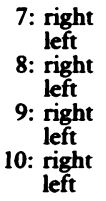 & $\begin{array}{r}20 \\
20 \\
132 \\
40 \\
20 \\
68 \\
505 \\
542\end{array}$ & $\begin{array}{r}3 \cdot 7 \\
4 \cdot 0 \\
2 \cdot 6 \\
2.6 \\
21 \cdot 9 \\
16.9 \\
2.9 \\
1.5\end{array}$ & $\begin{array}{l}0 \cdot 14 \\
0 \cdot 27 \\
0 \cdot 35 \\
0 \cdot 39 \\
- \\
1 \cdot 22 \\
0 \cdot 27 \\
0 \cdot 18\end{array}$ & $\begin{array}{c}20 \cdot 0 \\
25 \cdot 0 \\
3 \cdot 1 \\
3 \cdot 1 \\
\overline{400} \\
40 \cdot 0 \\
22 \cdot 4\end{array}$ & $\begin{array}{l}3 \cdot 2 \\
3 \cdot 7 \\
2 \cdot 5 \\
1 \cdot 9 \\
\overline{27} \cdot 8 \\
3 \cdot 0\end{array}$ \\
\hline
\end{tabular}

*For abbreviations see table 2 .

\section{Discussion}

The recent introduction of cytokine specific immunoassays has enabled us to examine synovial fluids to determine concurrently the concentration of five different cytokines and the relation between them. As far as we know such a study has not previously been reported.

Of the 111 fluids, tested $54(49 \%)$ contained IL- $1 \beta$ above the lowest detection limit of the assay $(20 \mathrm{pg} / \mathrm{ml})$. Eighty nine per cent of these fluids were from patients with inflammatory arthropathies (74\% RA; $15 \%$ seronegative arthropathy) compared with $11 \%$ from patients with non-inflammatory arthritides. Our findings of increased immunogenic concentrations of IL-1 $\beta$ in RA synovial fluids compare with measurements of functional activity by Ise $e t$ $a l,{ }^{21}$ Fontana $e t a l,{ }^{22}$ and Wood et al, ${ }^{23}$ and are supported by data showing production of IL-1 $\beta$ message $^{24}$ and IL-1 $\beta$ molecule ${ }^{24} 25$ by RA synovium.

We found lower concentrations of IL-2 in patients with the inflammatory arthropathies than in those with non-inflammatory arthritides, as previously reported. ${ }^{1}$ It has been suggested that complex formation between IL-2 and soluble IL-2 receptor accounts for the low concentrations of IL- 2 and down regulation of IL-2 dependent responses seen in RA, and positive correlations between IL-1 $\beta$ and both IL-2 and soluble IL-2 receptor have been reported. ${ }^{26}$ We were unable to find a correlation between IL-1 $\beta$ and IL-2 in 57 fluids from a similar patient group, however.

Tumour necrosis factor concentrations, which were lower in the inflammatory arthropathies than in osteoarthritis, correlated with IL-2 measurements, and this is consistent with evidence of IL-2 stimulated production of this cytokine. ${ }^{27}$ Many stimuli induce both IL-1 $\beta$ and TNF $\alpha$ and thus it was interesting that we found no correlation between these cytokines in the synovial fluids examined or between the concentrations of these cytokines and the number of cells found in the fluids. Our observations of increased TNF $\alpha$ in osteoarthritis may reflect the participation of this cytokine in cartilage resorption and inhibition of proteoglycan synthesis, and TNF $\alpha$ concentrations have been related to disease duration in osteoarthritis. ${ }^{28}$

The interferons alfa and gamma are thought to initiate the production of both pro- and antiinflammatory mediators through selective B cell activation. ${ }^{15}$ Our observation of a positive correlation between these cytokines suggests some sort of equilibrium between the potential tissue damaging and remodelling capabilities and may explain the high concentrations of both interferons measured in synovial fluids from nonarthritic subjects.

Cytokine concentrations measured in two healthy subjects were very similar to each other despite the fact that subject 1 produced fluid spontaneously, whereas in subject 2 sufficient fluid for aspiration was only generated as the result of exercise. When measurements in healthy subjects were compared with those in patients IL-1 $\beta$ concentrations were similar to those in the non-inflammatory group. Inter- 


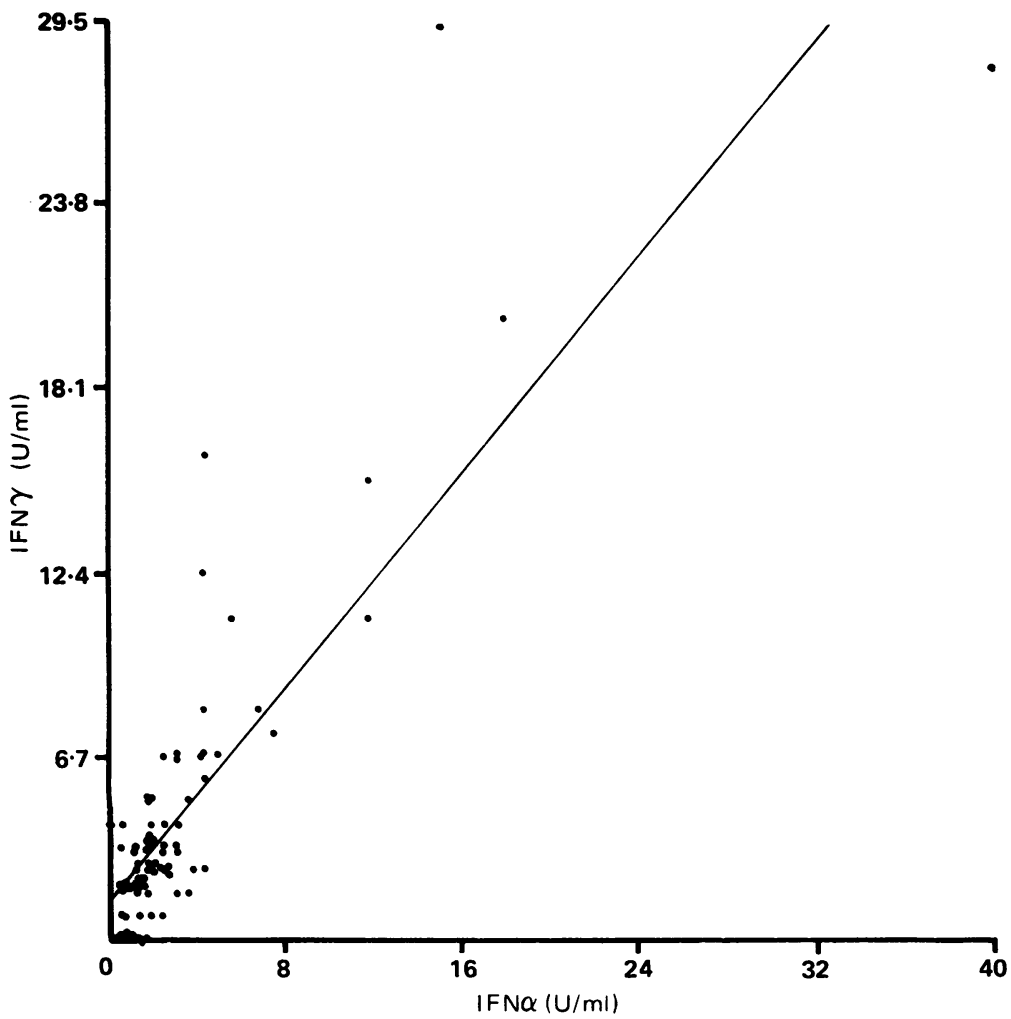

Figure 5 Correlation between the interferons alfa (IFN $)$ and gamma $(I F N \gamma)$ in synovial fluids from all three diagnostic groups $(n=80)$. Spearman's rank correlation coefficient $r=0.7 ; p<0.001$.

Table 5 Cytokine concentrations in sequential synovial fluid samples from patients with rheumatoid arthritis

\begin{tabular}{|c|c|c|c|c|c|c|c|}
\hline $\begin{array}{l}\text { Patient } \\
\text { No }\end{array}$ & $\begin{array}{l}\text { Time } \\
\text { (months) }\end{array}$ & $\begin{array}{l}I L-1 \beta^{*} \\
(p g / m l)\end{array}$ & $\begin{array}{l}I L-2 \\
(U / m l)\end{array}$ & $\begin{array}{l}T N F \alpha \\
(\mathbf{n g} / \mathbf{m l})\end{array}$ & $\begin{array}{l}I F N \alpha \\
(U / m l)\end{array}$ & $\begin{array}{l}I F N \gamma \\
(U / m l)\end{array}$ & $\begin{array}{l}\text { Serum } \\
C R P^{*} \\
(m g / m l)\end{array}$ \\
\hline 11 & $\begin{array}{l}0 \\
8\end{array}$ & $\begin{array}{r}80 \\
130\end{array}$ & $\begin{array}{l}1 \cdot 6 \\
4 \cdot 0\end{array}$ & $\begin{array}{l}0.11 \\
0.44\end{array}$ & $\overline{12} \cdot 0$ & $\overline{2 \cdot 5}$ & $\begin{array}{l}100 \\
150\end{array}$ \\
\hline 4 & $\begin{array}{l}\mathbf{0} \\
3\end{array}$ & $\begin{array}{l}320 \\
970\end{array}$ & $\begin{array}{l}2 \cdot 1 \\
6 \cdot 6\end{array}$ & $\begin{array}{l}0.1 \\
0.74\end{array}$ & $\overline{13} \cdot 4$ & $\overline{1 \cdot 0}$ & - \\
\hline
\end{tabular}

${ }^{*}$ For abbreviations see table $2 ; \mathrm{CRP}=\mathrm{C}$ reactive protein.

Table 6 Cytokine concentrations in sequential synovial fluid samples from patients with osteoarthritis

\begin{tabular}{|c|c|c|c|c|c|c|}
\hline $\begin{array}{l}\text { Patient } \\
\text { No: knee }\end{array}$ & $\begin{array}{l}\text { Time } \\
\text { (months) }\end{array}$ & $\begin{array}{l}I L-1 \beta^{*} \\
(p g / m l)\end{array}$ & $\begin{array}{l}I L-2 \\
(U / m l)\end{array}$ & $\begin{array}{l}T N F \alpha \\
(n g / m l)\end{array}$ & $\begin{array}{l}I F N \alpha \\
(U / m l)\end{array}$ & $\begin{array}{l}I F N \gamma \\
(U / m l)\end{array}$ \\
\hline $\begin{array}{c}\text { 12: right } \\
\text { left }\end{array}$ & $\begin{array}{l}0 \\
9 \\
0 \\
9\end{array}$ & $\begin{array}{l}20 \\
20 \\
20 \\
40\end{array}$ & $\begin{array}{l}6 \cdot 6 \\
5 \cdot 1 \\
5 \cdot 9 \\
6 \cdot 2\end{array}$ & $\begin{array}{l}0.55 \\
0.55 \\
- \\
0.82\end{array}$ & $\frac{\overline{20}}{\overline{40}}$ & $\frac{\overline{1 \cdot 7}}{7 \cdot 8}$ \\
\hline $\begin{array}{l}\text { 13: left } \\
\text { right }\end{array}$ & $\begin{array}{l}0 \\
5 \\
0 \\
5\end{array}$ & $\begin{array}{r}20 \\
78 \\
20 \\
128\end{array}$ & $\begin{array}{l}3 \cdot 7 \\
3.7 \\
3.0 \\
3.9\end{array}$ & $\begin{array}{l}0.54 \\
0.43 \\
0.43 \\
0.42\end{array}$ & $\begin{array}{l}3 \cdot 1 \\
3 \cdot 1 \\
-\end{array}$ & $\begin{array}{l}4 \cdot 7 \\
2 \cdot 2 \\
- \\
-\end{array}$ \\
\hline
\end{tabular}

${ }^{*}$ For abbreviations see table 2.

Table 7 Cytokine concentrations in sequential synovial fluid samples from patients with seronegative spondarthritis

\begin{tabular}{|c|c|c|c|c|c|c|}
\hline $\begin{array}{l}\text { Patient } \\
\text { No: knee }\end{array}$ & $\begin{array}{l}\text { Time } \\
\text { (months) }\end{array}$ & $\begin{array}{l}I L-I \beta^{*} \\
(p g / m l)\end{array}$ & $\begin{array}{l}I L-2 \\
(U / m l)\end{array}$ & $\begin{array}{l}T N F \alpha \\
(n g / m l)\end{array}$ & $\begin{array}{l}I F N \alpha \\
(U / m l)\end{array}$ & $\begin{array}{l}I F N \gamma \\
(U / m l)\end{array}$ \\
\hline 14 & $\begin{array}{r}0 \\
4 \\
10 \\
0 \\
3 \\
8\end{array}$ & $\begin{array}{l}20 \\
20 \\
20 \\
20 \\
20 \\
20\end{array}$ & $\begin{array}{l}0.5 \\
3.1 \\
2.2 \\
1.9 \\
3.0 \\
2.9\end{array}$ & $\begin{array}{l}0.10 \\
0.11 \\
0.31 \\
0.12 \\
0.37 \\
0.38\end{array}$ & $\begin{array}{r}8 \cdot 4 \\
21 \cdot 6 \\
13 \cdot 0 \\
13 \cdot 2 \\
28 \cdot 0 \\
17 \cdot 0\end{array}$ & $\begin{array}{l}1.6 \\
1.5 \\
2.1 \\
2.5 \\
\frac{3.4}{3.4}\end{array}$ \\
\hline $\begin{array}{c}\text { 16: right } \\
\text { left }\end{array}$ & $\begin{array}{l}0 \\
0 \\
5 \\
0 \\
5\end{array}$ & $\begin{array}{l}40 \\
65 \\
30 \\
74\end{array}$ & $\begin{array}{l}1 \cdot 7 \\
4 \cdot 18 \\
1 \cdot 2 \\
4 \cdot 7\end{array}$ & $\begin{array}{l}0 \cdot 1 \\
0 \cdot 45 \\
0 \cdot 1 \\
0 \cdot 48\end{array}$ & $\begin{array}{l}17.5 \\
16 \cdot 5 \\
17 \cdot 3\end{array}$ & $\begin{array}{l}\frac{1}{7.38} \\
2 \cdot 6 \\
3 \cdot 8\end{array}$ \\
\hline
\end{tabular}

*For abbreviations see table 2 .
Table 8 Synovial fluid cytokine concentrations in healthy subjects

\begin{tabular}{llllll}
$\begin{array}{l}\text { Subject } \\
\text { No }\end{array}$ & $\begin{array}{l}I L-1 \beta^{*} \\
(p g / m l)\end{array}$ & $\begin{array}{l}I L-2 \\
(U / m l)\end{array}$ & $\begin{array}{l}\text { TNFa } \\
(\mathrm{ng} / \mathrm{ml})\end{array}$ & $\begin{array}{l}I F N \alpha \\
(U / m l)\end{array}$ & $\begin{array}{l}I F N \gamma \\
(U / m l)\end{array}$ \\
\hline 1 & 20 & $13 \cdot 2$ & $1 \cdot 32$ & 200 & $16 \cdot 0$ \\
2 & 20 & $17 \cdot 0$ & 1.43 & 500 & $11 \cdot 3$
\end{tabular}

*For abbreviations see table 2 .

leukin-2, TNF $\alpha$, and interferon alfa and gamma concentrations were considerably higher in fluids from healthy subjects than in those from most patients and were comparable only with measurements obtained in one RA fluid (table 3).

Although these results are intriguing, they are difficult to substantiate or interpret. The amount of fluid in most normal knee joints is insufficient to aspirate enough to assay. These subjects may be abnormal, though it is noteworthy that they had relatively high concentrations of many cytokines but no joint damage. Measurement of these five cytokines concurrently in fluids from healthy subjects has not previously been reported as far as we know.

Great variation was seen in the patterns of cytokine concentration between different patients, particularly in the group with $R A$, although, interestingly, we did not measure any RA fluids in which all cytokines were very high. The fluid containing the highest measured amount of IL-1 $\beta(970 \mathrm{pg} / \mathrm{ml})$ contained only moderate amounts of other cytokines (table 3). The apparently independent nature of IL-1 $\beta$ was reflected in the fluids from healthy subjects as well as in many patient fluids, and in effusions from both knees of the same patient. For example, patients 8 and 10 (table 4) show a different IL-1 $\beta$ concentration in the left knee effusion than in the right, though IL-2 and TNF $\alpha$ concentrations were similarly low in all four fluids.

Studying sequential samples of synovial fluid from the same patient affords a different perspective on cytokine interrelationships. In patients with osteoarthritis (table 6) changes in IL-1 $\beta$ concentrations over time were not accompanied by changes in other cytokines, whereas in the seronegative group (table 7) results were more variable. Samples from two patients in the group with RA (table 5) both showed corresponding increases in all cytokines. In patient 11 these corresponded with an increase in inflammation, as indicated by an increase of serum $C$ reactive protein, and a worsening of clinical indices.

In some circumstances cytokine concentrations may reflect inflammatory disease activity. Little is known about the dynamics of synovial fluid and the exchange of molecules with the circulatory system. Because of the many and varied interactions of these five cytokines the relative proportions of each in synovial fluid are likely to be more important in the disease process and in predicting outcome than their presence in itself. Our continuing studies will therefore include an attempt to correlate these patterns with clinical indices and radiological changes measured over several years. 
We would like to thank the Medical Research Council and the Arthritis and Rheumatism Council for financial support. We are also grateful to Maryse Goodall for her skilled technical assistance.

1 Emery P, Williamson D J, MacKay I R. Role of cytokines in rheumatological inflammation. Concepts of Immunopathology 1987; 4: 171-9.

2 Gowen M, Wood D D, Ihrie E J, McGuire M K B, Russell R G. An interleukin- 1 like factor stimulates bone resorption in vitro. Nature 1983; 306: 378-80.

3 Thomson B M, Mundy G R, Chambers T.J. Tumour necrosis factor $\alpha$ and $\beta$ induce osteoblastic cells to stimulate osteoclast bone resorption. F Immunol 1987; 138: 775-9.

4 Saklatvala J, Sarsfield S J, Townsend Y. Pig interleukin-1: purification of two immunologically different leucocyte proteins that cause cartilage resorption lymphocyte activation and fever. $\mathcal{F}$ Exp Med 1985; 162: 1208-21.

5 Saklatvala I. Tumour necrosis factor-alpha stimulates resorption and inhibits synthesis of proteoclycan in cartilage. tion and inhibits synthe

6 Stashenko P, Dewhirst F E, Peros W J, Kent R L, Ago J M. Synergistic interactions between interleukin-1 tumour necrosis factor and lymphotoxin in bone resorption. f Immunol 1987; 138: 1464-7.

7 Oppenheim J J, Kovacs E J, Matsushima K, Durum S K. There is more than one interleukin. Immunology Today 1986; 7: 45-56.

8 Le J, Vilcek J. Tumour necrosis factor-alpha and interleukin-1: cytokines with multiple overlapping biological activities. Lab Invest 1987; 56: 234-48.

9 Last-Barry K, Homon C A, Faanes R B, Merluzzi V J. Synergistic and overlapping activities of tumour necrosis factor-alpha and interleukin-1. $f$ Imomonol 1988; 111: factor-al

10 Dinarello C A, Cannon J G, Wolff S M. Tumour necrosis factor (cachectin) is an endogenous pyrogen and induces production of interleukin-1. $\mathcal{F}$ Exp Med 1986; 163: $1433-49$.

11 Bachwich P R, Chensue S W, Larrick J W, Kunkel S. Tumour necrosis factor stimulates interleukin-1 and prostaglandin $\mathbf{E}_{2}$ production in resting macrophages. Biochem Biophys Res Commun 1986; 136: 94-101.

12 Warner S J, Auger K R, Libby P. Human interleukin-1 induces interleukin-1 gene expression in human vascular induces interleukin-1 gene expression in human vasc

13 Brinckerhoff C E, Guyre P M. Increased proliferation of human synovial fibroblasts treated with recombinant interferon-gamma. F Immunol 1985; 134: 3142-6.

14 Pober J S, Gimbone M A, Lapierre L A, et al. Overlapping patterns of activation of human endothelial cells by interleukin-1 tumour necrosis factor-alpha and interferongamma. F Immunol 1986; 137: 1893-6.

15 Browning I. Interferons and rheumatoid arthritis: insight into interferon biology. Immunology Today 1987; 8: 372-4.

16 diGiovine F S, Symons J A, Manson J, Duff G W. Soluble mediators of immunity: interleukins. In: Goodacre J, Dick C, eds. Immunopathogenic mechanisms in arthritis. Lancaster: MTP Press, 1988: 101-21.

17 Dayer J M, Beutler B, Cerami A. Cachectin/tumour necrosis factor-alpha stimulates collagenase and prostaglandin production by human synovial cells and dermal fibroblasts. production by human synovial cell

18 Tiku M L, Leisch J B, Robertson F M. Chondrocytes produce oxygen radicals after treatment with ConA, gamma interferon or tumour necrosis factor. Proceedings of the $52 \mathrm{nd}$ annual meeting of the American Rheumatism Association. Houston, Texas: American Rheumatism Association, 1988: Abstract B59.

19 Rosa F, Fellous $M$. The effect of interferon-gamma on MHC antigens. Immunology Today 1984; 5: 261-2.

20 Janossy G, Panayi G, Duke O, Bofill M, Poulter L W, Goldstein G. Rheumatoid arthritis: a disease of T-lymphocyte-macrophage immunoregulation. Lancet 1981; ii: cyte-macro 42 .

21 Ise $K$, Nakamura $S$, Ohkawara $S$, Yoshinga $M$. DNA synthesis-potentiating activity of mouse thymocytes of synovial fluid of rheumatoid arthritis patients. Acta Pathol fpn 1982; 32: 491-503.

22 Fontana A, Hengartner H, Weber E, Fehr K, Grob P J Cohen G. Interleukin-1 activity in the synovial fluid of patients with rheumatoid arthritis. Rheumatol Int 1982; 2 $49-53$

23 Wood D D, Ihrie E J, Dinarello C A, Cohen P I. Isolation of an interleukin-1 like factor from human joint effusion. Arthritis Rheum 1983; 26: 975-83.

24 Buchan G, Barrett $K$, Turner $M$. Chantry D, Maini $R$ N, Feldmann $M$. Interleukin-1 and tumour necrosis factor Feldmann $M$. Interleukin-1 and tumour necrosis factor mRNA expression in rheumatoid arthritis: prolonged

25 Duff $G W$, Dickens E, Wood N, et al. Immunoassay, bioassay and in situ hybridisation of monokines in rheumatoid arthritis. In: Powanda M C, Oppenheim J J, Kluger M, Dinarello C A, eds. Monokines and other non-lymphatic cytokines. New York: Alan R Liss, 1988: 387-92.

26 Symons J A, diGiovine F S, Eastgate J A, Wood N C, Capper $S \mathrm{~J}$, Duff G W. Interleukin-1 alpha and beta in rheumatoid arthritis: role in the potentiation of immune responses within the joint. Brf R Reumatol 1988; (suppl 2): 36 .

27 Nedwin G E, Sverdersky L P, Bringman T S, Palladino M A Goedell D V. Effect of interleukin-2, interferon-gamma Goedell D V. Effect of interleukin-2, interferon-gamma and mitogens on the production of tumour necrosi

28 di Giovine F S. Tumour necrosis factor in synovial fluid exudates. Ann Rheum Dis 1988; 47: 768-72. 